\title{
Nursing diagnoses of patients with kidney disease undergoing hemodialysis: a cross-sectional study
}

\author{
Diagnósticos de enfermagem de portadores de doença renal em hemodiálise: estudo transversal
}

Diagnósticos de enfermería de portadores de enfermedad renal en hemodiálisis: un estudio transversal

\section{Dandara Novakowski Spigolon', Elen Ferraz Teston', Fábio de Oliveira Souza', Bruna dos Santos', Rebeca Rosa de Souza', Antônio Moreira Neto'}

'Universidade Estadual do Paraná. Paranavaí, Paraná, Brazil.

How to cite this article:

Spigolon DN, Teston EF, Souza FO, Santos B, Souza RR, Moreira Neto A. Nursing diagnoses of patients with kidney disease undergoing hemodialysis: a cross-sectional study. Rev Bras Enferm [Internet]. 2018;71(4):2014-20.

DOI: http://dx.doi.org/10.1590/0034-7167-2017-0225

Submission: 03-22-2017 Approval: 09-18-2017

\begin{abstract}
Objective: to identify Nursing Diagnoses of $5^{\text {th }}$ stage chronic kidney disease patients undergoing hemodialysis. Method: cross-sectional, descriptive and quantitative study carried out with 151 patients undergoing hemodialysis in a clinic specialized in nephrology from the Northwest of the Paraná State. Nursing Diagnoses were determined through Nanda-I in which had the percentage greater than $50 \%$. The analysis used was the simple statistics. Results: 17 Nursing Diagnoses were identified, emphasizing the risks present in 100\% of patients: risks for electrolyte imbalance; ineffective kidney perfusion; infection: vascular injuries, adverse response to the iodinebased contrast-enhanced and impaired urinary elimination. Conclusion: the main diagnoses listed reflect the more frequent risks that patients undergoing hemodialysis are exposed to. Being aware of these risks allows the nursing planning with early interventions, in order to prevent complications related to the disease and to promote best life conditions.
\end{abstract}

Descriptors: Nursing Diagnosis; Kidney Dialysis; Chronic Kidney Disease; Nursing Processes; Renal Replacement Therapy.

\section{RESUMO}

Objetivo: identificar os Diagnósticos de Enfermagem de portadores de doença renal crônica em estádio 5 hemodialítico. Método: estudo transversal, descritivo, de abordagem quantitativa, realizado com 151 indivíduos em hemodiálise de uma clínica especializada em nefrologia na região Noroeste do Paraná. Foram determinados os Diagnósticos de Enfermagem por meio da Nanda-l que obtiveram o porcentual maior que $50 \%$. A análise utilizada foi a estatística simples. Resultados: foram identificados 17 Diagnósticos de Enfermagem, com destaques para os de riscos presentes em 100\% dos indivíduos: riscos de desequilíbrio eletrolítico; perfusão renal ineficaz; infecção: trauma vascular e resposta adversa ao meio de contraste com iodo e o de eliminação urinária prejudicada. Conclusão: os principais diagnósticos elencados refletem os riscos mais frequentes aos quais os pacientes em hemodiálise estão expostos. O conhecimento desses riscos permite o planejamento de enfermagem com intervenções precoces, com vistas à prevenção de complicações relacionadas à doença e promoção de melhores condições de vida.

Descritores: Diagnóstico de Enfermagem; Diálise Renal; Insuficiência Renal Crônica; Processos de Enfermagem; Terapia de Substituição Renal.

\section{RESUMEN}

Objetivo: identificar los Diagnósticos de Enfermería de portadores de enfermedad renal crónica en estadio 5 hemodialítico. Método: estudio transversal, descriptivo, de abordaje cuantitativo, realizado con 151 individuos en hemodiálisis de una clínica especializada en nefrología en la región Noroeste de Paraná. Se determinaron los Diagnósticos de Enfermería por medio de la Nanda-l que obtuvieron el porcentaje más alta al 50\%. El análisis utilizado fue la estadística simple. Resultados: se identificaron 17 Diagnósticos de Enfermería, con destaques para los de riesgos presentes en el 100\% de los individuos: riesgos de desequilibrio electrolítico; perfusión renal ineficaz; infección: trauma vascular y respuesta adversa al medio de contraste con yodo y el de eliminación urinaria perjudicada. Conclusión: los principales diagnósticos enumerados reflejan los riesgos más frecuentes a los cuales están expuestos los pacientes en 
hemodiálisis. El conocimiento de estos riesgos permite la planificación de enfermería con intervenciones tempranas, con miras a la prevención de complicaciones relacionadas con la enfermedad y promoción de mejores condiciones de vida.

Descriptores: Diagnóstico de Enfermería; Diálisis Renal; Insuficiencia Renal Crónica; Procesos de Enfermería; Terapia de sustitución renal.

\section{CORRESPONDING AUTHOR Dandara Novakowski Spigolon E-mail: dandaraspigolon@gmail.com}

\section{INTRODUCTION}

The number of patients with chronic kidney disease (CKD) has been increasing gradually and is considered a worldwide public health problem. In Brazil, the average number of $5^{\text {th }}$ stage CKD people undergoing hemodialysis reaches 112,004, which represents an average increase of 20,000 CKD patients in recent years, with a prevalence rate of dialysis treatment of 552 per million population ${ }^{(1)}$.

CKD is identified by abnormalities in kidney structure or renal function, present for more than three months, and progressive and irreversible loss of kidney function ${ }^{(2-3)}$. It reaches the $5^{\text {th }}$ stage undergoing hemodialysis when the Glomerular Filtration Rate is $<15 \mathrm{ml} / \mathrm{min} / 1.73 \mathrm{~m} 2$, which results in the most severe degree of the disease. This condition is characterized by the inability of the body to maintain homeostasis, accompanied in most cases by signs and symptoms of uremia and insufficiency of kidney function, leading to the need for Renal Replacement Therapy (RRT) for the maintenance of life $\mathrm{e}^{(4-5)}$.

Dialysis methods increase the survival rate of these patients, with kidney transplantation, peritoneal dialysis and hemodialysis (HD) as possible forms of RRT. HD is the most used method and is characterized by filtering and purifying blood, in order to maintain normal components, removing toxic substances from the body, as well as excess water ${ }^{(4,6)}$. However, these treatments, as well as the disease, directly compromise the way of life. In this context, it is essential to know the potential risk factors, sociodemographic and clinical profile of this group, factors that determine the susceptibility and cause of CKD.

For the integral and continuous care with the individuals, it is necessary a unique language among the nursing professionals. This is the reason why Nursing Diagnoses rely on the clinical judgment of the nurse to diagnose patterns of human responses to a potential (associated risk factors) or real (signs and symptoms) health problem, directing it to planning of nursing care, identifying their needs, which provides solutions, with health promotion and prevention of possible complications ${ }^{(7-9)}$. The taxonomy of nursing diagnoses officially recognized in the world is NANDA- $I^{(9)}$.

In this context, a study carried out in a hemodialysis unit at the Hospital de Clínicas (Clinics Hospital) of Porto Alegre city, identified a nursing diagnosis of 98 patients in hemodialysis, evidencing their importance for clinical nursing practice. It was also stressed that the establishment and execution of hemodialysis is an exclusive nursing assignment, which contributes to the development of the profession ${ }^{(10)}$.

Similarly, an integrative review study with searches conducted between 2002 and 2013, pointed out that the use of nursing diagnoses contribute to disseminate nursing practice, concepts and nursing care, reflecting the quality of care provided, since portray the real needs of individuals and, after identification, the nurse will have subsidies, through nursing interventions, to identify the actions necessary for their care ${ }^{(11)}$.

Several studies focusing on nursing diagnosis have been developed ${ }^{(6-8)}$. However, we still lack studies that reflect the specific risks of $5^{\text {th }}$ stage CKD patients undergoing hemodialysis in order to subsidize care planning aimed at preventing future complications. From this, this study aims to identify Nursing Diagnoses of $5^{\text {th }}$ stage CKD patients undergoing hemodialysis.

\section{OBJECTIVE}

To identify Nursing Diagnoses of $5^{\text {th }}$ stage CKD patients undergoing hemodialysis.

\section{METHOD}

\section{Ethical aspects}

This study is contained in the research project "Diagnóstico situacional da doença renal crônica no município e região noroeste do Paraná - perspectivas de uma assistência de enfermagem direcionada a terapia de substituição renal" (freely translated as Situational diagnosis of chronic kidney disease in the municipality and northwest region of Paraná - perspectives of a nursing care directed to Renal Replacement Therapy (IDEA)). It was approved by the Research Ethics Committee of the Universidade Estadual de Maringá. Individuals were approached after initiating HD sessions, initially oriented on the purpose of the study, and read with them the Informed Consent Form (ICF), evidencing all information about privacy, confidentiality and possible doubts present in the term. Thus, all participants who agreed to participate signed the ICF, delivered in two copies, remaining one with the participant and another with the researcher, according to the provisions of Resolution CNS (National Health Council) 510/2016.

\section{Design, place of study and period}

This is a cross-sectional, descriptive and quantitative research. The study place was a clinic specialized in nephrology in the Northwest region in the state of Paraná, Brazil. The data were collected through a form between July and August 2016.

\section{Sample and criteria of inclusion and exclusion}

The study sample comprised $5^{\text {th }}$ stage CKD patients undergoing hemodialysis. The inclusion criterion adopted was: being older than 18 years and having kidney disease undergoing hemodialysis. Pregnant women, psychiatric patients with cognitive problems or people with impaired comprehension of the study, transplanted patients and those who underwent dialysis treatment for less than 60 days, an estimated period for 
adaptation to dialysis treatment were excluded from the sample. Initially, there were 188 individuals enrolled at the study place undergoing hemodialysis. Of these, 13 were excluded considering the exclusion criteria (seven in psychiatric treatment with cognitive problems or impairment of study comprehension and three transplanted patients).

Thus, the sample size was obtained throughout the simple sample calculation using the formula $n=N . Z 2 . p .(1-p) / Z 2 . p .(1-p)+$ e2. ) The 175 selected individuals were considered, level of significance $(\alpha)$ of 0.05 , statistical power of the test of $95 \%$ and possibility of sample loss of $20 \%$, which resulted in a sample of 156 individuals. After the invitation to participate in the study, five individuals refused, which resulted in a final sample of 151, according to Figure 1.

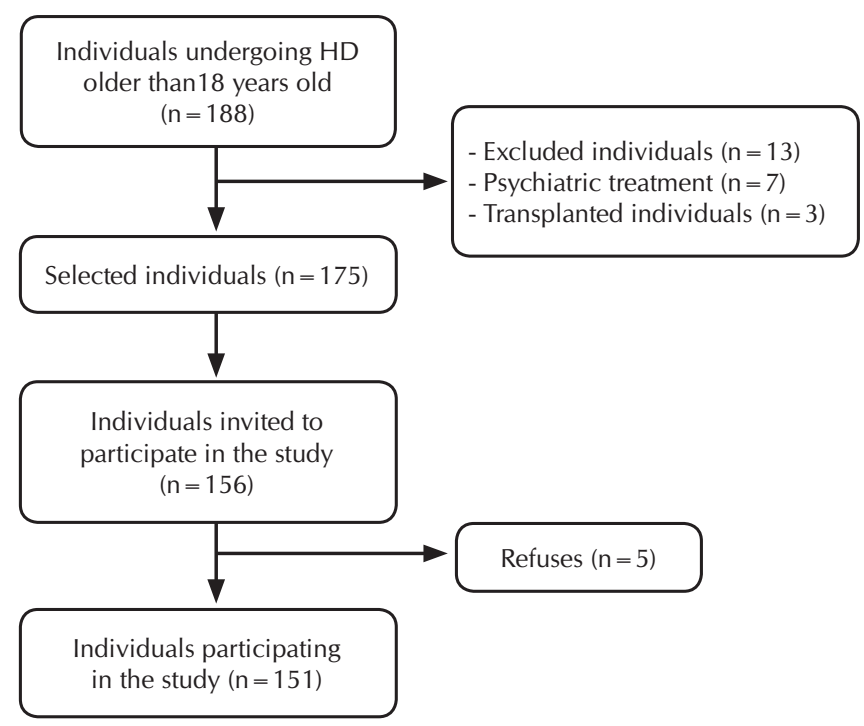

Note - Hemodiálise - HD

Figure 1 - Participant selection process and sample calculation, Northwest Region of Paraná, Paraná State, Brazil, 2016

\section{Study protocol}

Initially, a semi-structured tool for collecting data on the health and disease status of $5^{\text {th }}$ stage CKD patients undergoing hemodialysis was prepared by the authors themselves, based on an analysis in the literature with demographic, psychosocial, clinical and biochemical information. The tool was based on the Teoria das Necessidades Humanas (Theory of Human Basic Needs) by Wanda de Aguiar Horta ${ }^{(12)}$, in the Nursing Process based on COFEN Resolution 358/2009 ${ }^{(13)}$, in demographic and administrative data according to the Padronização de Registros Clínicos (Standardization of Medical Records) 11-12-1999 ${ }^{(14)}$. In addition, in other complementary references ${ }^{(4-5,15-16)}$ related to the subject of the study, allowing the survey of the risk factors and related and the main characteristics of individuals' health determinants.

Sequentially, a form with the main Nursing Diagnostics was constructed as a basis for identification, using as reference the NANDA-I, as the basis of the functional standards $\mathrm{s}^{(9)}$.

The data collection took place during the shifts and schedules of the HD sessions by the nursing academics duly trained by the researcher in charge. Each collection lasted an average of
25 minutes per individual, and it was also possible to access the medical records to complement the information pertinent to the study. According to the data collected, the defining characteristics and the related factors of each patient were determined for NANDA-I ${ }^{(9)}$. Finally, the tool for the identification of Nursing Diagnostics by CKD patients undergoing HD was used. The evidence of the nursing diagnoses was carried out by the academics and reviewed by the professors responsible.

\section{Analysis of results and statistics}

The categorical variables (Nursing Diagnostics identified) were transcribed to a spreadsheet, using the software Microsoft Excel 2013. Then, the information contained in the spreadsheet was transported to the software SPSS 2.0 (Statistical Package for the Social Sciences) to compile the obtained data. The analysis used was simple statistics, expressed in frequency and percentage, using YES for the Nursing Diagnosis that was identified in the individual and NO for what was not identified. From this, all Nursing Diagnoses were determined, which obtained a percentage greater than $50 \%$ (more frequent).

\section{RESULTS}

\section{Sociodemographic and clinical characterization}

Table 1 shows sociodemographic and clinical characteristics prevalent in the study participants.

Table 1 - Prevalent sociodemographic and clinical characteristics of 5th stage chronic kidney disease patients undergoing hemodialysis, Northwest Region of Paraná, Paraná State, Brazil, 2016

\begin{tabular}{lcc}
\hline \multicolumn{1}{c}{ Characteristics } & n & \% \\
\hline Male & 96 & 63.3 \\
Age above 60 years & 75 & 49.6 \\
Married & 84 & 55.6 \\
Incomplete elementary education & 82 & 54.3 \\
Retired & 66 & 43.7 \\
Receive Illness-Aid & 54 & 35.8 \\
Monthly income of up to two minimum wages & 100 & 66.2 \\
Type of dialysis funding by the Brazilian Unified & 141 & 93.4 \\
Health System (SUS) & 58 & 38.4 \\
Presented Systemic Arterial Hypertension & 51 & 33.8 \\
$\begin{array}{l}\text { Presented Systemic Arterial Hypertesnion with } \\
\text { diabetes mellitus }\end{array}$ & & \\
\hline
\end{tabular}

\section{Identification of Nursing Diagnoses}

From these data, we selected the 17 most frequent Nursing Diagnoses (Table 2).

Among the 17 diagnoses, six were present in all patients: 1) risk of electrolyte imbalance, 2) risk of ineffective kidney perfusion, 3) risk of infection, 4) risk of vascular injury, 5) risk of adverse response to the iodine-based contrast-enhanced and 6) impaired urinary elimination. 
Table 2 - Nursing diagnoses identified in 5th stage chronic kidney disease patients undergoing hemodialysis, Northwest Region of Paraná, Paraná State, Brazil, 2016

\begin{tabular}{lcc}
\hline \multicolumn{1}{c}{ Identified Nursing Diagnoses } & \multicolumn{2}{c}{ Individuals } \\
& $\mathbf{( N =} \mathbf{1 5 1 )}$ \\
& $\mathbf{n}$ & $\mathbf{\%}$ \\
\hline Sedentary life style & 86 & 57.0 \\
Provision for improved nutrition & 82 & 54.3 \\
Ineffective protection & 122 & 80.8 \\
Risk of electrolyte imbalance & 151 & 100.0 \\
Risk of dysfunctional gastrointestinal motility & 89 & 58.9 \\
Risk of impaired cardiovascular function & 131 & 86.8 \\
Risk of ineffective gastrointestinal perfusion & 135 & 89.4 \\
Risk of ineffective kidney perfusion & 151 & 100.0 \\
Risk of ineffective peripheral tissue perfusion & 116 & 76.8 \\
Risk of decreased cardiac tissue perfusion & 109 & 72.2 \\
Risk of ineffective cerebral tissue perfusion & 94 & 62.3 \\
Risk of adverse response to the iodine-based contrast-enhanced & 151 & 100.0 \\
Risk of infection & 151 & 100.0 \\
Risk of vascular injury & 151 & 100.0 \\
Risk of falls & 76 & 50.3 \\
Impaired urinary elimination & 151 & 100.0 \\
Chronic pain & 82 & 54.3
\end{tabular}

The main defining characteristics, related factors and risk factors according to the demographic, psychosocial, clinical and biochemical data were presented during the development of the diagnostic identification form (Chart 1).

Chart 1 shows the predominance of some characteristics common to all individuals, such as chronic condition, old age, treatment regimen, abnormal blood profile, medicine use and the main comorbidities.

\section{DISCUSSION}

The sociodemographic profile reflected the tendency of previous studies in the face of population aging and the increase in the incidence of chronic diseases, which contribute to the worldwide increase in the prevalence of CKD ${ }^{(17)}$. Because of this, the number of elderly patients undergoing hemodialysis is gradually increasing. However, the presence of other comorbidities, age limitations and the presence of HD complications also compromise the health vulnerabilities of these individuals ${ }^{(17-20)}$.

Chart 1 - Defining characteristics and related factors in the definition of the identified Nursing Diagnoses

\begin{tabular}{|c|c|c|}
\hline Domain (Class) & Nursing Diagnoses & Defining characteristics, related factors and risk factors \\
\hline $\begin{array}{l}\text { Health Promotion } \\
\text { (Health Perception) }\end{array}$ & Sedenary lifestyle & Poor knowledge about the benefits that physical activity brings to health. \\
\hline $\begin{array}{l}\text { Health Promotion } \\
\text { (Health Control) }\end{array}$ & Ineffective protection & Old age, abnormal blood profiles, medicine therapies and/or side effects. \\
\hline $\begin{array}{l}\text { Nutrition } \\
\text { (Ingestion) }\end{array}$ & $\begin{array}{l}\text { Provision for improved } \\
\text { nutrition }\end{array}$ & Expresses desire for improvement in nutrition. \\
\hline $\begin{array}{l}\text { Nutrition } \\
\text { (Hydration) }\end{array}$ & Risk of electrolyte imbalance & $\begin{array}{l}\text { Excessive or insufficient fluid volume, renal dysfunction and treatment } \\
\text { regimen. }\end{array}$ \\
\hline $\begin{array}{l}\text { Elimination and Exchange } \\
\text { (Gastrointestinal function) }\end{array}$ & $\begin{array}{l}\text { Risk of dysfunctional } \\
\text { gastrointestinal motility }\end{array}$ & Anxiety, chronic disease, immobility and medicines. \\
\hline \multirow{6}{*}{$\begin{array}{l}\text { Activity/Rest } \\
\text { (Cardiovascular / } \\
\text { Pulmonary responses) }\end{array}$} & $\begin{array}{l}\text { Risk of impaired } \\
\text { cardiovascular function }\end{array}$ & $\begin{array}{l}\text { Age } \geq 65 \text { years, chronic diseases, dyslipidemia, family history of cardiovascular } \\
\text { disease, smoking, history of cardiovascular disease and sedentary lifestyle. }\end{array}$ \\
\hline & $\begin{array}{l}\text { Risk of ineffective } \\
\text { gastrointestinal perfusion }\end{array}$ & $\begin{array}{l}\text { Anemia, vascular/circulatory disease, renal disease, smoking and treatment } \\
\text { regimen. }\end{array}$ \\
\hline & $\begin{array}{l}\text { Risk of ineffective kidney } \\
\text { perfusion }\end{array}$ & Kidney disease. \\
\hline & $\begin{array}{l}\text { Risk of ineffective peripheral } \\
\text { tissue perfusion }\end{array}$ & Diabetes mellitus, hypertension, sedentary lifestyle and smoking. \\
\hline & $\begin{array}{l}\text { Risk of decreased cardiac } \\
\text { tissue perfusion }\end{array}$ & $\begin{array}{l}\text { Cardiovascular surgery, diabetes mellitus, family history of cardiovascular } \\
\text { disease, hyperlipidemia and hypertension. }\end{array}$ \\
\hline & $\begin{array}{l}\text { Risk of ineffective cerebral } \\
\text { tissue perfusion }\end{array}$ & Hypercholesterolemia and hypertension. \\
\hline $\begin{array}{l}\text { Safety/Protection } \\
\text { (Deffensive Processes) }\end{array}$ & $\begin{array}{l}\text { Risk of adverse response to the } \\
\text { iodine-based contrast-enhanced }\end{array}$ & Chronic kidney disease. \\
\hline $\begin{array}{l}\text { Safety/Protection } \\
\text { Infection }\end{array}$ & Risk of infection & $\begin{array}{l}\text { Invasive procedure, alteration in skin integrity, smoking and chronic } \\
\text { disease. }\end{array}$ \\
\hline $\begin{array}{l}\text { Safety/Protection } \\
\text { (Injury) }\end{array}$ & Risk of vascular injury & Presence of catheter. \\
\hline $\begin{array}{l}\text { Safety/Protection } \\
\text { (Injury) }\end{array}$ & Risk of falls & $\begin{array}{l}\text { Age }>65 \text { years, weakness, anemia, walking difficulties and visual } \\
\text { difficulties. }\end{array}$ \\
\hline $\begin{array}{l}\text { Elimination and Exchange } \\
\text { (Urinary function) }\end{array}$ & Impaired urinary elimination & Several reasons. \\
\hline $\begin{array}{l}\text { Comfort } \\
\text { (Physical comfort) }\end{array}$ & Chronic pain & Chronic condition and fatigue. \\
\hline
\end{tabular}


Of the 17 Nursing Diagnoses, 12 were considered to correspond to the risks arising from the clinical and therapeutic condition, as well as to the habits of life. It was also observed that six of them were identified in all CKD patients undergoing hemodialysis treatment. Therefore, it is necessary to have a differentiated and qualified perception of this group of individuals in a more enlightening way with the aim of improving nursing care.

Renal dysfunction is a defining characteristic that is present in all participants, leading to the identification of the risk of electrolyte imbalance. The main characteristic of $5^{\text {th }}$ stage CKD patients undergoing hemodialysis is the loss or decrease of the glomerular filtration process, provoking electrolytic and metabolic imbalance, impairing homeostasis in the organism ${ }^{(5)}$, as well as endocrine dysfunction that directly compromises renal function, preventing the metabolic and absorption of minerals such as calcium, causing hypocalcemia(21). The water disturbance may aid in electrolyte imbalance. Therefore, the use of diuretics, which are mostly indicated for blood pressure control, can lead to electrolyte changes such as hypokalemia ${ }^{(22)}$. Another therapeutic concern in maintaining regulated intracorporeal fluid is precisely to avoid adverse effects on the clinical state of these patients with CKD undergoing HD. In this sense, nursing can avoid possible complications, identifying signs and symptoms that indicate insufficient intake, loss or excessive accumulation of fluid, as well as other electrolytic alterations ${ }^{(6)}$.

The risk of ineffective renal perfusion may also be associated with the factors highlighted in the study, such as the treatment regimen of the CKD patient undergoing HD. Given the complexity of this treatment, nursing plays an important role in promoting and preventing these diseases, such as encouraging adherence to physical exercises, improving diet, abolishing smoking and using medicines to control basic diseases. These actions, besides contributing to reduce the chance of occurrence of cardiovascular diseases, minimize the process of tissue injury resulting from an unsatisfactory tissue perfusion ${ }^{(17,21,23)}$.

On the other hand, the risk of adverse response to the iodine-based contrast-enhanced being defined by NANDA as a risk of harmful or unintentional response associated with the use of iodine-based contrast-enhanced may lead to dehydration, which is a well-defined risk factor for decrease or loss of renal function after the use of contrast mean ${ }^{(9)}$. Therefore, this is mainly related to the presence of CKD. However, other underlying diseases, extreme age, fragile vein, could be used as secondary characteristics to identify this diagnosis. The use of contrast to perform procedures, such as imaging, must follow protocols for their administration in patients with CKD, or in individuals who have other risk factors for the development of contrast-induced nephropathy, causing an increase in serum creatinine in up to 48 hours after perfusion. Therefore, preventive measures should be used when the use of contrast is indispensable ${ }^{(20)}$. Nurses should be aware of risk factors, as well as measures focused on the protection and prevention of possible complications.

The risk of infection is present in all participants, mainly associated with puncture in arteriovenous fistula or the presence of a double-lumen catheter for HD. The maintenance of the fistula with the catheter depends on both the care of the nursing team and the patient himself. The disinfection of the insertion site, the exposure of the catheter and several punctures to the fistula are factors that increase the risk of infection ${ }^{(18)}$. Infection is the second leading cause of death among patients with kidney disease $\mathrm{e}^{(21)}$, and the relationship with access to HD sessions, the presence of secondary causes such as diabetes and other chronic diseases, immune status of the individual, smoking, change in the integrity of the skin, malnutrition and obesity contribute to this. Informing patients about treatment and self-care may contribute to reducing the risk of infection ${ }^{(6)}$.

The risk of vascular injury has also been identified in all participants and is related to the presence of the catheter due to its inadequate fixation, insertion site and its period of permanence, which causes hematoma at the site or even more severe vascular complications such as stenosis and thrombosis venous $^{(23)}$. The healing time and inadequate care with arteriovenous fistula may compromise the local vascular system as well as the rate of rapid perfusion during HD sessions. The nursing team should inspect the insertion site of the catheter as well as the arteriovenous fistula, considering the signs that indicate the vascular injury such as the presence of hematoma, when deciding the rate of perfusion during $\mathrm{HD}^{(6)}$.

Present in all participants, impaired urinary elimination is related to the presence of alterations caused by the decrease of the Glomerular Filtration Rate, being unable to perform the regulatory functions and to remove the products of metabolic degradation, also causing alteration in the quantity and frequency of urination. The presence of anuria or oliguria and/or nocturia are therefore determinants for the diagnosis ${ }^{(5,18-19)}$.

The results found in the present study strengthen important points in the care of $5^{\text {th }}$ stage CKD patients undergoing hemodialysis, showing the need of nursing care, focused mainly on health promotion and risk prevention in face of their basic human psychosocial and psychobiological needs.

\section{Study limitations}

This study had as limitations the accomplishment in a single center of dialysis, which can be influenced by the characteristics peculiar to the region, and a small edition. In addition, another limitation was related to the non-validation of nursing diagnoses by external experts, and were determined and analyzed by the two teachers involved in the research, providing continuity for future studies.

Contributions to the nursing, health and public policy sectors CKD patients undergoing HD suffered impairments due to the disease effects itself, as well as to the treatment. Thus, the specificities of the defining characteristics, related factors and risk factors found in this study subsidize as a starting point for the identification of nursing diagnoses, and thus, may favor important information for the targeted and integral planning of the care of these individuals. In this sense, it contributes to the execution of the nursing process in a more scientific and less empirical way, which may lead to a better performance of clinical care for CKD patients under dialysis, in the daily practice of nurses. 


\section{CONCLUSION}

The identification of the main nursing diagnoses in chronic kidney disease patients undergoing hemodialysis treatment allowed the determination of the main risks related to this pathology. These risks should be included in the daily planning of nursing care, since the nurse is the professional who assumes direct care in this type of treatment. It is hoped that the current study may contribute to future research on nursing interventions to CKD patients undergoing $\mathrm{HD}$, aiming at a better implementation of this assistance.

\section{REFERENCES}

1. Sesso RC, Lopes AA, Thomé FS, Lugon JR, Martins CT. Brazilian chronic dialysis census 2014. J Bras Nefrol[Internet]. 2016[cited 2016 Apr 18];38(1):54-61. Available from: http://www.scielo.br/pdf/jbn/v38n1/en_0101-2800-jbn-38-01-0054.pdf

2. Inker LA, Astor BC, Fox CH, Isakova T, Lash JP, Peralta CA, et al. KDOQI US commentary on the 2012 KDIGO clinical practice guideline for the evaluation and management of CKD. Am J Kidney Dis[Internet]. 2014[cited 2016 Apr 18];63(5):713-35. Available from: https://www.kidney.org/sites/default/files/docs/inker_et_al_ajkd_ckd_commentary_epub.pdf

3. Kidney Disease: Improving Global Outcomes-KDIGO. CKD Work Group. KDIGO 2012 clinical practice guideline for the evaluation and management of chronic kidney disease. Kidney Int Suppl[Internet]. 2013[cited 2016 Apr 18];3:1-150. Available from: http:// www.kdigo.org/clinical_practice_guidelines/pdf/CKD/KDIGO_2012_CKD_GL.pdf

4. Daugirdas JT, Blake PG, Ing TS. Manual de diálise. 13th ed. Rio de Janeiro: Guanabara Koogan; 2016.

5. National Kidney Foundation-KDOQI clinical practice guideline for hemodialysis adequacy: 2015 update. Am J Kidney Dis[Internet]. 2015[cited 2016 Apr 18];66(5):884-930. Available from: http://www.ajkd.org/article/S0272-6386(15)01019-7/pdf

6. Santana SS, Taynnkelle F, Magalhães LM. Assistência de enfermagem prestada aos pacientes em tratamento hemodialítico nas unidades de nefrologia. Rev Científ ITPAC[Internet]. 2013[cited 2016 Jun 10];6(3):1-11. Available from: http://www.itpac.br/ arquivos/Revista/63/5.pdf

7. Frazão CM, Medeiros AB, Silva FB, Sá JD, Lira AL. Nursing diagnoses in chronic renal failure patients on hemodialysis. Acta Paul Enferm[Internet]. 2014[cited 2016 Sep 10];27(1):40-43. Available from: http://www.scielo.br/pdf/ape/v27n1/0103-2100ape-27-01-00040.pdf

8. Silva PLN, Quintiliano ACBA, Souto SGT, Oliveira RS, Gonçalves RPF, Paiva PA. Perception of nurses regarding the systematization of nursing care to the chronic renal patient. J Nurs UFPE[Internet]. 2015[cited 2016 Sep 10];9(12):1168-73. Available from: http:// www.revista.ufpe.br/revistaenfermagem/index.php/revista/article/viewArticle/6888

9. Nanda Internacional. Diagnósticos de enfermagem da Nanda: definições e classificações, 2015-2017. 10th ed. Porto Alegre: Artmed; 2015.

10. Dallé J, Lucena AF. Nursing diagnoses identified in hospitalized patients during hemodialysis. Acta Paul Enferm[Internet]. 2012[cited 2017 May 19];25(4):504-10. Available from: http://dx.doi.org/10.1590/S0103-21002012000400004

11. Souza Neto VL, Sucupira PA, Brandão RS, Virgolino FSS, Silva RAR, Mendonça AEO. Clinical reasoning in construction of nursing diagnosis: integrative review. J Nurs UFPE[Internet]. 2015[cited 2017 May 19];9(2):936-44. Available from: https://periodicos.ufpe. $\mathrm{br} / \mathrm{revistas} /$ revistaenfermagem/article/view/10419/0

12. Horta WA. Processo de Enfermagem. São Paulo: EPU/Edusp; 1979.

13. Brasil. Conselho Federal de Enfermagem. Resolução COFEN 358/2009[Internet]. 15 Oct 2009[cited 2016 May 4]. Available from: http://www.cofen.gov.br/resoluo-cofen-3582009_4384.html

14. Brasil. Ministério de Estado da Saúde. Portaria 3947/GM em 25 de novembro de 1998[Internet]. Padronização de registros clínicos - PRC. Conjunto essencial de informações do prontuário para integração da informação em saúde. SOP001/98; 1999[cited 2016 May 4]. Available from: http://pesquisa.bvs.br/brasil/resource/pt/normativos-526

15. Medeiros RC, Sousa MNA, Nunes RMV, Sampaio CTS, Moraes JC, Diniz MB. Health-related quality of life of individuals under hemodialysis. J Nurs UFPE[Internet]. 2015[cited 2016 Sep 10];9(Supl-9):1018-27. Available from: http://www.revista.ufpe.br/ revistaenfermagem/index.php/revista/article/viewArticle/5328

16. Duarte PS, Miyazaki MCOS, Ciconelli RM, Sesso R.[Translation and cultural adaptation of the quality of life assessment instrument for chronic renal patients (KDQOL-SFTM)]. Rev Assoc Med Bras[Internet]. 2003[cited 2016 Sep 10];49(4):375-381. Available from: http://www.scielo.br/pdf/ramb/v49n4/18335.pdf Portuguese

17. Magalhães FG, Goulart RMM. Chronic kidney disease and its treatment in the elderly: an integrative review. Rev Bras Geriatr Gerontol[Internet]. 2015[cited 2016 Sep 10];18(3):679-92. Available from: http://www.scielo.br/pdf/rbgg/v18n3/en_1809-9823rbgg-18-03-00679.pdf

18. Poveda VB, Alves JS, Santos EF, Garcia EMA. Nursing diagnoses in patients undergoing hemodialysis. Enferm Glob[Internet]. 2014[cited 2017 Mar 17];13(34):58-69. Available from: http://scielo.isciii.es/pdf/eg/v13n34/en_clinica3.pdf

19. Santos ACB, Machado MC, Pereira LR, Abreu JLP, Lyra MB. Association between the level of quality of life and nutritional status 
in patients undergoing chronic renal hemodialysis. J Bras Nefrol[Internet]. 2013[cited 2017 Mar 17];35(4):279-88. Available from: http://www.scielo.br/pdf/jbn/v35n4/en_v35n4a08.pdf

20. Bass EB, Subramaniam RM. Prevention strategies for contrast-induced nephropathy. Ann Intern Med[Internet]. 2016[cited 2017 Mar 17];165(8):601. Available from: http://annals.org/aim/article/2569398/prevention-strategies-contrast-induced-nephropathy

21. Lins SMSB, Santo FHE, Fuly PSC, Garcia TR. Subset of ICNP ${ }^{\circledR}$ diagnostic concepts for patients with chronic kidney disease. Rev Bras Enferm[Internet]. 2013[cited 2016 Sep 10];66(2):180-9. Available from: http://www.scielo.br/pdf/reben/v66n2/05.pdf

22. Wang HH, Hung CC, Hwang DY, Kuo MC, Chiu YW, Chang JM, et al. Hypokalemia, its contributing factors and renal outcomes in patients with chronic kidney disease. PLoS One[Internet]. 2013[cited 2016 Sep 10];8(7):1-9. Available from: http://journals.plos. org/plosone/article/file?id =10.1371/journal.pone.0067140\&type = printable

23. Mendonça NN, Dutra MD, Funghetto SS, Stival MM, Lima LR. Nursing diagnoses of patients on hemodialysis in use of doublelumen catheter. Rev Enferm Cent O Min[Internet]. 2013[cited 2016 Sep 10];3(2):632-44. Available from: http://www.seer.ufsj.edu. br/index.php/recom/article/view/335/440 